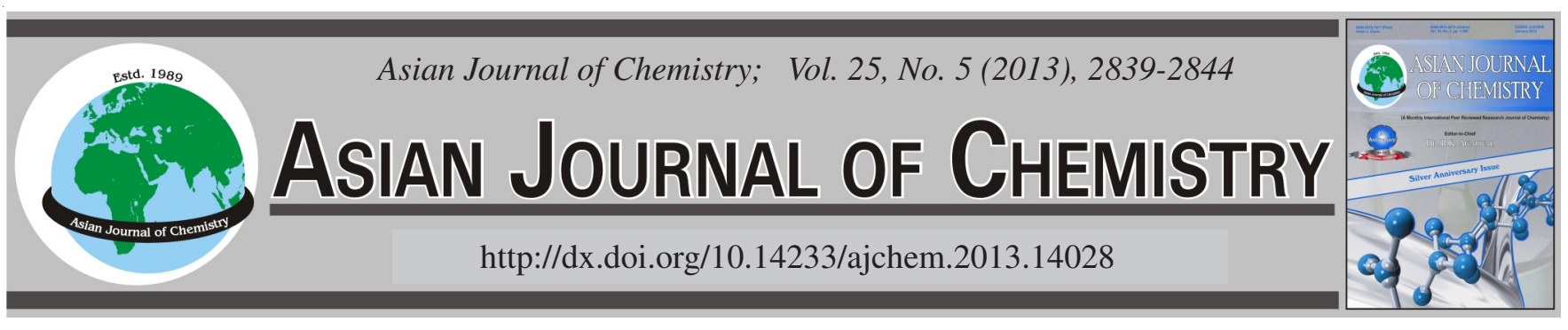

\title{
Heap Bioleaching of Refractory Arsenic Gold Concentrates
}

\author{
Dong-Hui Cheng ${ }^{1, *}$, JiAng-TAO HE ${ }^{2}$ and Guo-Bin $\mathrm{Li}^{3}$
}

${ }^{1}$ School of Environmental Sciences and Engineering, Chang'an University, Xi'an 710054, P.R. China

${ }^{2}$ School of Water Resources and Environment, China University of Geosciences, Beijing 100083, P.R. China

${ }^{3}$ Northwest Geological Research Institute of CNPC, Lanzhou 730020, P.R. China

*Corresponding author: Fax: +86 29 85585485; Tel: +86 29 82339951; E-mail: cdh101@126.com

(Received: 8 May 2012;

Accepted: 26 November 2012)

AJC-12465

\begin{abstract}
In this work, we pretreated refractory arsenic gold concentrate, obtained from the Shaanxi Pangjiahe mine located in Feng county, Shaanxi, China, by heap bioleaching with Acidithiobacillus ferrooxidans (A.f.). The purpose of this research was to evaluate the feasibility of heap bioleaching on refractory gold concentrate. The samples with an agglomerate agent were bio-leached within a temperature range of $15-28^{\circ} \mathrm{C}$ for periods of $60 \mathrm{~d}, 132 \mathrm{~d}$ and $306 \mathrm{~d}$, respectively, in leaching column. Then the residues were cyanide leached. The highest gold extraction rate increased from $39.97 \%$, which is the gold extraction rate from the direct cyanidation process, to $88.66 \%$. Our results demonstrate that the Au extraction rate was linear with the As extraction rate. The redox potential of $\mathrm{Fe}^{3+} / \mathrm{Fe}^{2+}$ is the primary potential in the leaching solution and the T.f. activity varied periodically with inhibition and accommodation. Heap bioleaching can probably be applied on refractory gold concentrate. Further study should be carried out to determine ways to shorten the bioleaching time.
\end{abstract}

Key Words: Refractory, Arsenic gold concentrate, Heap bioleaching, Column experiments.

\section{INTRODUCTION}

Since biooxidation has been used in pretreatment of refractory sulfidic gold ores, a few techniques and patent have been developed for this process, such as BIOX, BacTech, MINBAC, BIONC, bio-leaching ${ }^{1,2}$. The main leaching processes include agitated tank bioleaching and heap bioleaching. The former process is aimed at the refractory gold concentrate and is in two stages. In the first of bioleaching stage, the sulfide mineral is decomposed partly by bioleaching and in the second or leaching gold stage, the CIP (carbon-in-pump) or RIP (resin-in-pump) is applied. Application of this process results in higher extraction, but also has higher investment and costs. Tank bioleaching is not generally economical for use on low-grade concentrate, or for small projects which can not support a high capital investment. Heap bioleaching, which has a low investments and costs aimed generally at refractory and low-grade raw gold ores, has already been successfully applied on ores from some mine, but research on low-grade gold concentrate has seldom been done previously ${ }^{3}$. The only process, known as GEOCOAT, had been developed to treat concentrate which is coated onto a crushed and sized carrier rock $^{1,4}$. The main objective of the present study reported here was to investigate the possibility of pretreating refractory low-grade gold concentrate by heap bioleaching with the agglomerated sample.

\section{EXPERIMENTAL}

The sample was obtained from the Pangjiahe gold mine, Feng county, western Shaanxi Province, China. The sample is from micro-disseminated gold deposits. Gold is hosted in epizonal metamorphic fragmentary rock in the upper Devonion series. In the sample, the sulfide minerals are mainly pyrite, arsenopyrite and small amounts of galena and blende. The pyrite contains $46.97 \%$ sulfer and $44.19 \%$ ferrous, which is lower than the standard pyrite. The arsenic content is up to $3.18 \%$ in pyrite. Gold-bearing minerals mainly include pyrite, arsenopyrite and clay minerals in the ore (Table-1). The concentrate floatation technique was used at the mine. The clay minerals flow into the tailings in the flotation process, thus the gold-bearing minerals in the concentrate are pyrite and arsenopyrite. The concentrate contains $34-40 \mathrm{~g} / \mathrm{t}$ gold. The recovery of gold from direct cyanidation leaching is $30-40 \%$ only.

TABLE-1

GOLD PARTITIONING OF ORE IN PANGJIAHE GOLD DEPOSIT

\begin{tabular}{lccc}
\hline Mineral & $\begin{array}{c}\text { Mineral } \\
\text { composition }(\%)\end{array}$ & $\begin{array}{c}\text { Gold comp- } \\
\text { osition }(\mathrm{g} / \mathrm{t})\end{array}$ & $\begin{array}{c}\text { Gold partition } \\
\text { in mineral }(\%)\end{array}$ \\
\hline Pyrite & 6.8 & 72.6 & 41.97 \\
Arsenopyrite & 0.5 & 222.0 & 9.45 \\
Clays & 92.1 & 6.2 & 48.58 \\
Total & 99.4 & - & 100.00 \\
\hline
\end{tabular}


The forms of gold in these minerals are native gold and silver-gold with micro- and sub-microscopic particles. In the microscopic gold, which has a particle diameter below 0.04 $\mathrm{mm}$, the metal occurs in the forms of included-gold, inclusion gold and fissure-filled gold in the gold-bearing minerals. In the submicroscopic gold, the metal occurs in tiny fissures of micro-pyrite, as precipitates on the mineral surface, or is adsorbed on the mineral's border. Submicroscopic gold particles range from $0.025-0.42 \mu \mathrm{m}$ in diameter ${ }^{5}$.

Sample chemical analyses indicate that the concentrate contains $16.45 \%$ S, $3.32 \%$ As and 30-40 g/t Au. About $85 \%$ of the concentrate particles are less than $0.074 \mathrm{~mm}$ in diameter.

A mixed culture of iron- and sulphur-oxidizing microorganisms origined from mine water in Inner Mongolia and Guangdong was used in present experiment. The main bacteria strains were Acidithiobacillus ferrooxidans in this culture. The bacteria strains were adaptively cultured in shakes using pyrite and arsenopyrite concentrate as a substrate. The conditions for bacterial growth in the solution were as follows: $35^{\circ} \mathrm{C}$, 120-160 rpm, pH 1.8 and $9 \mathrm{~K}$ medium modified without iron, namely, $\left(\mathrm{NH}_{4}\right)_{2} \mathrm{SO}_{4}: 0.45 \mathrm{~g} / \mathrm{L}, \mathrm{KCl}: 0.10 \mathrm{~g} / \mathrm{L}, \mathrm{K}_{2} \mathrm{HPO}_{4}: 0.15 \mathrm{~g} / \mathrm{L}$, $\mathrm{MgSO}_{4} \cdot 7 \mathrm{H} 2 \mathrm{O}: 0.50 \mathrm{~g} / \mathrm{L}, \mathrm{Ca}\left(\mathrm{NO}_{3}\right)_{2}: 0.01 \mathrm{~g} / \mathrm{L}$. The bacterial cultures were tested by assessing their acid production and by microscopic cell counting in a Thoma's chamber. When the culture was in the exponential growth phase (around $10^{8}$ bacterial $/ \mathrm{mL}$ ) the concentrate sample was taken to inoculate a bioleaching experiment.

Analytical methods: The bacterial cell number in each bio-oxidation solution was determined by directly counting using an optical microscope with a Thoma's counting chamber. Total iron and $\mathrm{Fe}^{2+}$ were determined by titration with a standard solution of potassium dichromate with and without the prereductant stannous chloride. $\mathrm{Fe}^{3+}$ was calculated using the difference between the concentrations of total iron and total iron and $\mathrm{Fe}^{2+}$. The total soluble arsenic concentration in the bio-oxidation leachates was determined by colourimetric analysis. The gold in the solution was determined by flame atomic absorption spectrometry and the $\mathrm{pH}$ of the cultural suspension and gold extractive solution was monitored with a $\mathrm{pH}$ meter.

For all experiments, analytical grade reagent and distilled water were used with the exception of the chemical analyses in which double distilled water was used.

Experimental method: Column bioleachings were performed in four Plexiglass columns each with an inner diameter of $75 \mathrm{~mm}$ and a height of $1000 \mathrm{~mm}$. Four column, $\mathrm{C}_{1}, \mathrm{C}_{2}, \mathrm{C}_{3}$ and $\mathrm{C}_{4}$, with different bioleaching time, 0, 60, 132 and $306 \mathrm{~d}$, were set up to evaluate the effect of the arsenic oxidation process. They contain the concentrate materials with weight of $6.00,6.40,6.30$ and $6.60 \mathrm{~kg}$, respectively. Feed solution was pumped through the column filter with a peristaltic pump.

It is well known that the fine material in heap leaching may cause low recovery duo to reduced heap permeability. This problem is commonly solved by agglomeration pretreatment prior to heap leaching. Because the bioleaching process is in the acid media, thus our material was agglomerated using acid resistant cement, $4 \mathrm{~g} / \mathrm{kg}$, in order to improve the permeability of leaching system before loading into the column.
The materials in the columns were washed using diluted sulfuric acid 0.03-0.15 $\mathrm{M}$ in order to keep pH steady at 1.82.0, then leached continuously using $4 \mathrm{~L}$ solution inoculated with $1 \mathrm{~L}$ microbial suspension in active growth in a $9 \mathrm{~K}$ medium without ferrous sulphate and with a leaching rate of $0.2-0.3$ $\mathrm{L} / \mathrm{kgod}$. The feed solution was aerated continuously in order to provide enough soluble oxygen during bioleaching.

At the end of bioleaching, the bioleaching residues were neutralized and alkalinized. Subsequently, they were submitted to the process of cyanidation by both stirring leaching and column leaching for gold extraction. In addition, the $\mathrm{C}_{4}$ bioleaching residues at the top of column were stirring leached by cyanidation on the 192nd and 252nd day. The stirring cyanide leaching was carried out in a glass reactor at $50 \%(\mathrm{w} / \mathrm{v})$ pulp density for $48 \mathrm{~h}$ with diluted alkaline cyanide solutions (0.5-5 kg/t Ca(OH) 2 , pH 11.0 and $15 \mathrm{~kg} / \mathrm{t} \mathrm{NaCN})$ at atmospheric pressure and room temperature $\left(20{ }^{\circ} \mathrm{C}\right)$. The solid/ liquid (S/L) weight ratio was held at $1 / 2$.

At the end of the tests, the solid residues and the residual solution were submitted to gold analysis.

In addition, two series of agitated bio-oxidation tests were carried out in 1000 -mL beakers at room temperature $\left(20^{\circ} \mathrm{C}\right)$ for oxidation time of $10 \mathrm{~d}$ and $20 \mathrm{~d}$ respectively, at $10 \%$ (w/v) pulp density. At the end of the bioleaching tests, the solid residues were filtered, washing with distilled water, dried at $105^{\circ} \mathrm{C}$ and weighed. Subsequently, they were submitted to stirring cyanide leaching and the cyanide leaching conditions are as mentioned above.

All the column bioleaching solution were collected at regular intervals of 5 day to analyze for total $\mathrm{Fe}, \mathrm{Fe}^{2+}, \mathrm{Fe}^{3+}$, As, $\mathrm{pH}$ and Eh in bioleaching solution. All the bioleaching residues were analyzed for $\mathrm{As}$ and $\mathrm{S}$.

To evaluate the percentage of total oxidation of the mineral, As and Fe precipitated during bioleaching tests were determined. Sample of $1 \mathrm{~g}$ of solid residue were treated for $30 \mathrm{~min}$ at room temperature, by $10 \mathrm{~mL}$ of $\mathrm{HCl} 5 \mathrm{M}$. The analysis of Fe and As was performed.

\section{RESULTS AND DISCUSSION}

Extraction rate of gold: The extraction rates of $\mathrm{Au}, \mathrm{As}$ and $S$ through time are listed in Table-2. The results of the experiment show that the Au extraction in the column 1 materials was 30-40\% in which the direct cyanidation process was operated by either column leaching or agitated leaching. This result indicates that the gold-bearing minerals in 30-40\% of the sample occur in the forms of fissure-fills.

In the column 2, column 3 and column 4, the Au extraction increased with the bio-oxidation time (Table-2), but not in a perfectly linear relationship with time. In the first $60 \mathrm{~d}$, the $\mathrm{Au}$ extraction increased rapidly. Then during 60 to $132 \mathrm{~d}$ the $\mathrm{Au}$ extraction increased less than $1 \%$. Finally during 132 to 306 $\mathrm{d}$, the Au extraction increased much more slowly than during the first $60 \mathrm{~d}$. Although the Au extraction of the bio-oxidation sample (column 2, 3 and 4) did not yield a satisfactory result, the extraction is still higher than that for no bio-oxidation of the sample (column 1).

In addition, the gold extraction of material at the top of column 4 on the 252 nd day of the bio-oxidation time was up to $86.66 \%$, which is higher than the gold extraction of the 
TABLE-2

EXTRACTION RATE OF GOLD, ARSENIC AND SULFUR

\begin{tabular}{|c|c|c|c|c|c|c|c|}
\hline & Extraction $(\%)$ & \multicolumn{6}{|c|}{ Biooxidation time (d) } \\
\hline \multirow{3}{*}{$\mathrm{Au}$} & \multirow{3}{*}{$\begin{array}{l}\text { Column cyanidation } \\
\text { Agitated cyanidation }\end{array}$} & 0 (column 1$)$ & $60($ column 2) & $132($ column 3$)$ & $306($ column 4) & $192^{*}$ & $252^{*}$ \\
\hline & & 39.97 & 49.67 & $\begin{array}{l}50.34 \\
\end{array}$ & 79.82 & - & - \\
\hline & & 30.62 & 49.63 & 51.12 & 79.73 & 75.23 & 86.66 \\
\hline As & & 0 & 14.16 & 17.77 & 78.31 & 66.57 & 88.86 \\
\hline$S$ & & 0 & 7.84 & 18.66 & 28.88 & 38.12 & 55.08 \\
\hline
\end{tabular}

remaining material on the 306th d of bio-oxidation time, 79.73 $\%$. Different effects of bio-oxidation exist at different heights of the columns and obviously the material at the top of the column yielded a better bio-oxidation result than that in the bottom. This may result from differing oxygen supply at different heights. The oxygen was sufficient in the top of column, while it was reduced on the bottom due to rapid oxygen consumption.

Another point deserving of special mention is that gold extractions by column cyanidation leaching and by agitated cyanidation leaching for bio-oxidation residue show little difference (Table-2 and Fig. 1). There is less than $1 \%$ difference in each pair of cyanidation leachings, thus indicated that it would be feasible to recover gold by heap leaching of the bioleaching residue.

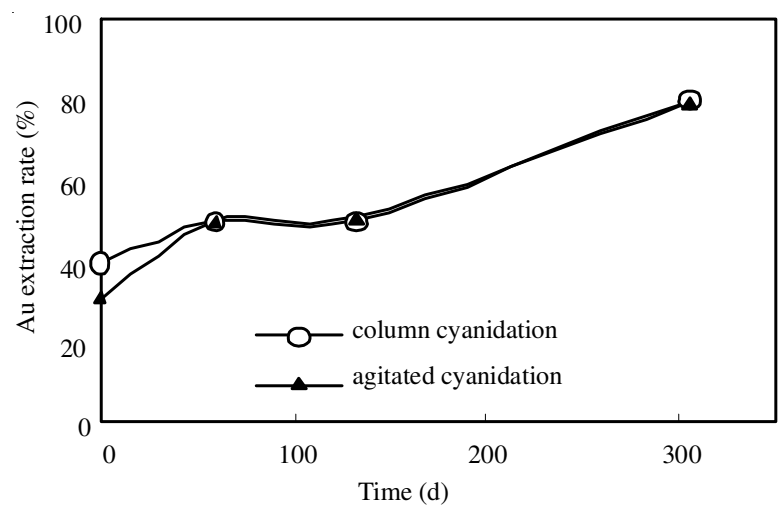

Fig. 1. Change of extraction rates of gold change with biooxidation time

Extraction rate of arsenic and sulfur: The iron in biooxidation solution is an indication of the pyrite oxidation, while the appearance of soluble arsenic is due to arsenopyite degradation. Sulphate in the bio-oxidation solution is formed as a result of the bio-oxidation of both minerals.

Whether column cyanidation or agitated cyanidation are used after column bioleaching, the Au extraction rate was positively proportional to the As extraction rate, especially when the As extraction rate was greater than $14 \%$. A linear relation was present (Fig. 2), which can be expressed as follow:

$$
\mathrm{Y}=2.06 \mathrm{X}-85.07
$$

here $\mathrm{Y}$ denotes the As extraction rate and $\mathrm{X}$ denotes the $\mathrm{Au}$ extraction rate.

In agitated bioleaching-agitated cyanidation, the relationship between the Au and As extraction was the same as above. The experimental result indicated that the gold-bearing minerals are pyrite and arsenopyrite.

The relationship between the extraction of the $\mathrm{S}$ and $\mathrm{Au}$ exhibited more scattering than As in all the experiments (Fig. 3), but the gold extraction corresponds to the sulfur extraction and the gold extraction increased with the increase of sulfur extraction.

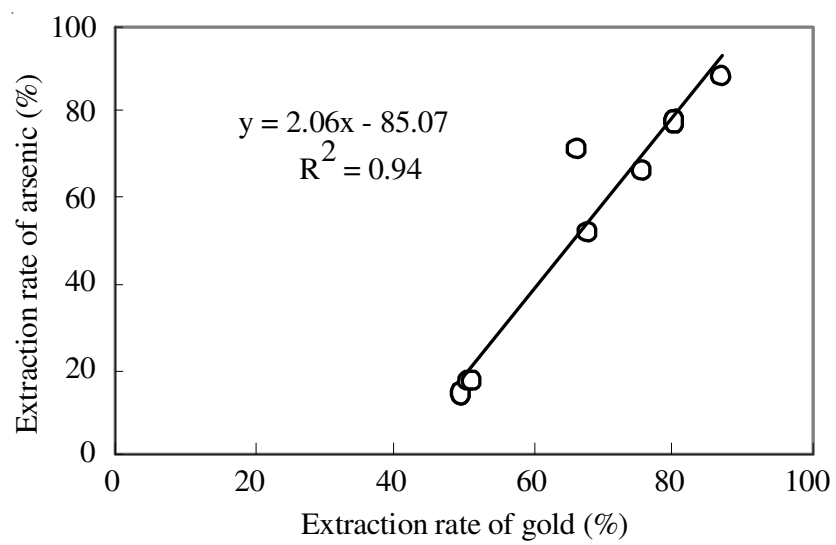

Fig. 2. Linear extraction rate relationship between gold and arsenic

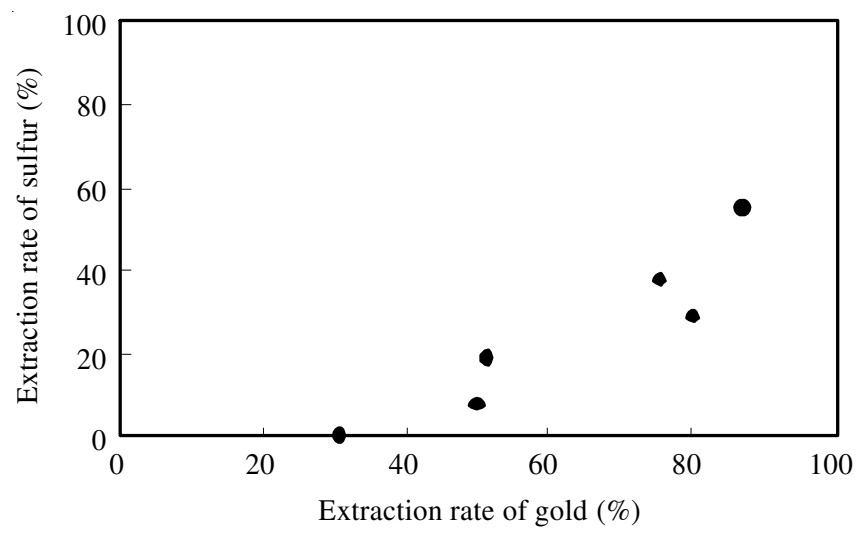

Fig. 3. Extraction relationship between gold and sulfur

Furthermore, in the agitated bio-oxidation experiment, the higher gold extraction appeared in the same sulfur extraction as in the experiment in column bio-oxidation. When the sulfur extraction rate was $7.5 \%$ in both, the gold extraction was up to $66 \%$ in agitated bioleaching, while in column bioleaching, it was only about $49 \%$. Considering that the same gold extraction occurred with the same arsenic extraction in both leaching methods, this result reveals the preferential biooxidation on arsenopyrite in agitated bioleaching ${ }^{6}$.

Eh and the iron concentration: The Eh observed value was compared to the Eh calculated value in order to evaluate the main ions effect on the Eh of the effluent solution. If only the half-reaction of $\mathrm{Fe}^{3+} / \mathrm{Fe}^{2+}$ is taken into account, the calculated potential was $750-850 \mathrm{mV}$ (Eh2 in Fig. 4). The potential was measured using a potential difference meter. The working electrode is $\mathrm{Pt}$ and reference electrode is the calomel electrode. 


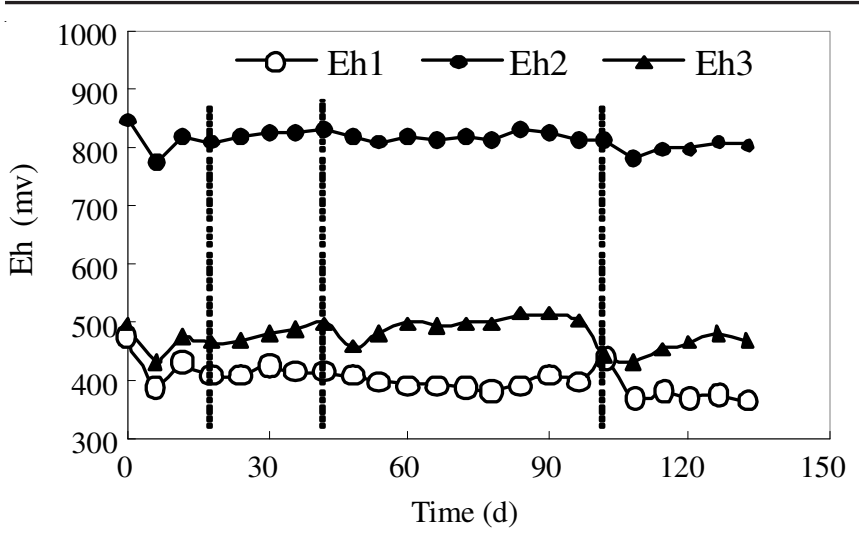

Fig. 4. Relationship between Eh measured and calculated in oxidation solution in column 3

Eh $($ observed $)=$ Eh $($ half-cell $)-$ Eh $($ standard half-cell $)$

In the primary cell, the reaction includes:

$$
\text { Positive: } \begin{array}{cc}
\mathrm{Fe}^{3+}+\mathrm{e} \rightarrow \mathrm{Fe}^{2+} & \mathrm{E}_{0}=0.771 \mathrm{mv} \\
2 \mathrm{H}^{+}+2 \mathrm{e} \rightarrow \mathrm{H}_{2} & \mathrm{E}_{0}=0.000 \mathrm{mv}
\end{array}
$$

Negative: $2 \mathrm{Hg}(l)+2 \mathrm{Cl}^{-} \rightarrow \mathrm{Hg}_{2} \mathrm{Cl}_{2}+2 \mathrm{e} \mathrm{E}_{0}=0.268 \mathrm{mv}$

While potential measurement was performed by the calomel electrode, the standard half-cell refers to $\mathrm{Hg}_{2} \mathrm{Cl}_{2} / \mathrm{Hg}$. Its standard oxidation-reduction potential in saturated solution of $\mathrm{KCl}$ is $241.2 \mathrm{mV}$. $\mathrm{H}^{+} / \mathrm{H}_{2}$.

In the measured solution, only considering $\mathrm{Fe}^{3+} / \mathrm{Fe}^{2+}$ and

Eh $($ calculated $)=\mathrm{Eh}\left(\mathrm{Fe}^{3+} / \mathrm{Fe}^{2+}\right)+\mathrm{Eh}\left(\mathrm{H}^{+} / \mathrm{H}_{2}\right)-\mathrm{Eh}\left(\mathrm{Hg}_{2} \mathrm{Cl}_{2} / \mathrm{Hg}\right)(5)$

Fig. 4 shows the calculated results (Eh3 in Fig. 5) and shows that the calculated potential was close to the observed value and that the difference was of $23-122 \mathrm{mV}$.

Hence, in the bioleaching effluent solution, the observed oxidation-reduction potential is affected by the multi-electron pair potential. The potential of $\mathrm{Fe}^{3+} / \mathrm{Fe}^{2+}$ was the primary one (Fig. 5).

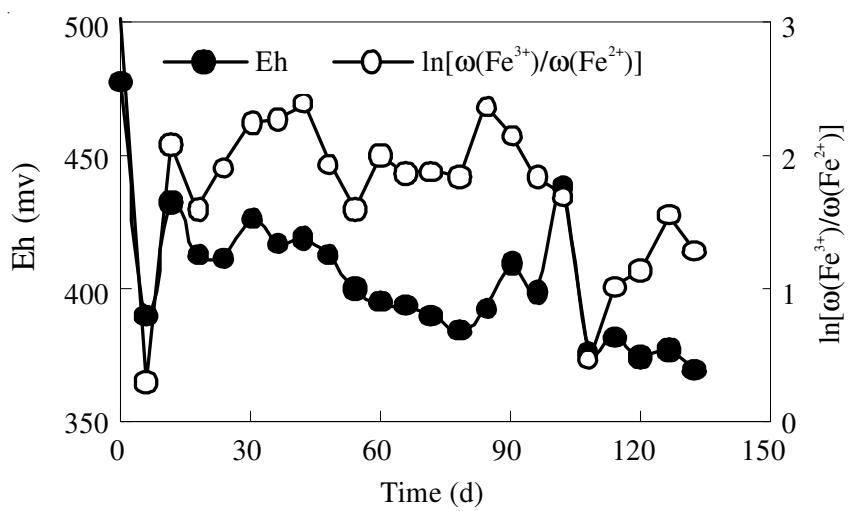

Fig. 5. Relationship between Eh and Fe ions in oxidation solution in column 3

In addition, the redox potential was represented by the descending trend during the oxidation period (Fig. 4). This trend showed the accumulation of ferrous ion and was a sign of low-activity of the bacterial solution ${ }^{7,8}$.

TFe and As concentration: A number of studies confirmed the precipitation of $\mathrm{Fe}$ and As, thus the $\mathrm{Fe}$ and $\mathrm{As}$ in bioleaching solution was not the all of the Fe and As dissolved by bioleaching. The Fe and As concentration, however, was strictly related to the activity of bacterial ${ }^{9-12,7}$. In our work, for the column 3 only at the $12^{\text {th }}, 48^{\text {th }}$ and $102^{\text {nd }}$ day, part of the leaching solution was replaced. Fig. 6 shows the trend of the total $\mathrm{Fe}$ and As concentrations and their increased concentrations ( $\Delta \mathrm{TFe}$ and $\Delta \mathrm{As}$ ) in the solution over the entire bioleaching period. The TFe and As concentrations increased in the the $12^{\text {th }}-48^{\text {th }}$, the $48^{\text {th }}-102^{\text {nd }}$ and the $102^{\text {nd }}-132^{\text {nd }} d$ periods, which reflected the continuous dissolution process of sulfide minerals. The $\Delta \mathrm{TFe}$ and $\Delta \mathrm{As}$ concentrations periodically fluctuated, which suggests that the periodical activity of bacterial. In the initial stage, due to renewing the solution, TFe and As concentrations were low and the bacteria have strong activity. But increasing the $\mathrm{Fe}$ and As concentration because of sulfide minerals dissolution inhibited the activity of bacteria and at the same time, the bacteria started to adapt to the high Fe and As concentration. The bacteria exhibited activity again after adapting to high ions concentration, but finally their activity was inhibited again at even higher Fe and As concentrations. Each process during three periods can be divided into four stages according to the activity (Fig. 6): I. Activity stage; II. Inhibition stage; III. Resumption stage; and IV. Re-inhibition stage (Fig. 6a and 6b). In the first and third stages, the TFe and As concentrations increased rapidly and in the second and fourth stage, slowly.

The periodical stages mentioned above are also related to the bioleaching mechanism. The bioleaching process can release principal metals from sulfide minerals by direct and indirect bacterial leaching. In direct bacterial leaching, there is physical contact between the bacterial cell and the mineral sulfide surface and the oxidation to sulfate take place via several enzymatically catalyzed steps. Pyrite is oxidized according to the following reaction ${ }^{13-15}$.

$$
\begin{gathered}
2 \mathrm{FeS}_{2}+7 \mathrm{O}_{2}+2 \mathrm{H}_{2} \mathrm{O}=2 \mathrm{FeSO}_{4}+2 \mathrm{H}_{2} \mathrm{SO}_{4} \\
4 \mathrm{FeSO}_{4}+\mathrm{O}_{2}+2 \mathrm{H}_{2} \mathrm{SO}_{4}=2 \mathrm{Fe}_{2}\left(\mathrm{SO}_{4}\right)_{3}+2 \mathrm{H}_{2} \mathrm{O}
\end{gathered}
$$

In indirect bioleaching the bacteria generate a lixiviant which chemically oxidizes the sulfide minerals. In acid solution this lixiviant is ferric iron. Pyrite solubilization by ferric iron can be described according to the following reaction:

$$
\mathrm{FeS}_{2}+2 \mathrm{Fe}_{2}\left(\mathrm{SO}_{4}\right)_{3}=3 \mathrm{FeSO}_{4}+2 \mathrm{~S}
$$

The bioleaching mechanism of arsenopyrite is the same as pyrite.

In the first stage, the activity of the bacteria is strong and direct bioleaching is primary; in second stage, the chemical process (indirectly) is primarily due to the increase of $\mathrm{Fe}^{3+}$ concentration and inhibition of bacteria; in third stage, there exist both direct and indirect processes; and in last stage, the chemical reactions return again.

Based on the above discussion, it is predicted that the third period should appear which has already been shown partly in Fig. 6a and 6b. Thus in the process of bioleaching, the bacteria has adapted to the higher ionic concentration continuously and their activity shows periodicity. Due to the long adaptation time in heap bioleaching, the bioleaching process was extended in experiment.

Fig. 6 also shows that the first wave crest is higher than the second one, which indicated that the activity of the bacteria did not recover from its initial level and the inhibition effectiveness continued. 


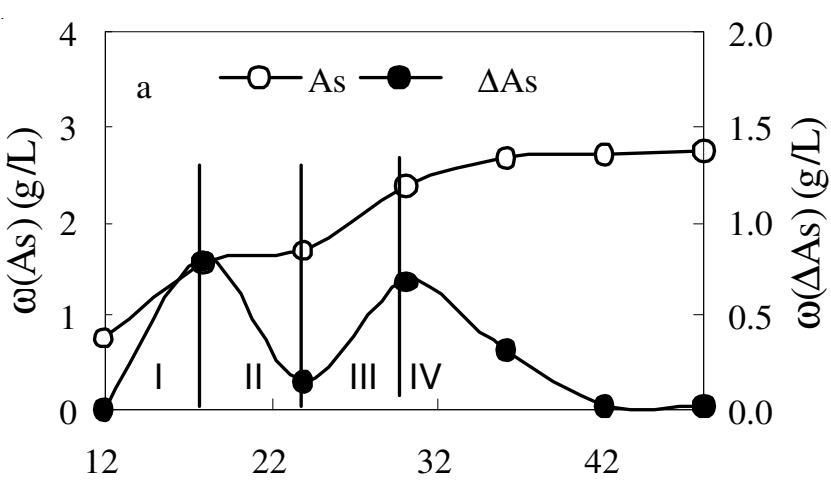

Time $(\mathrm{d})$
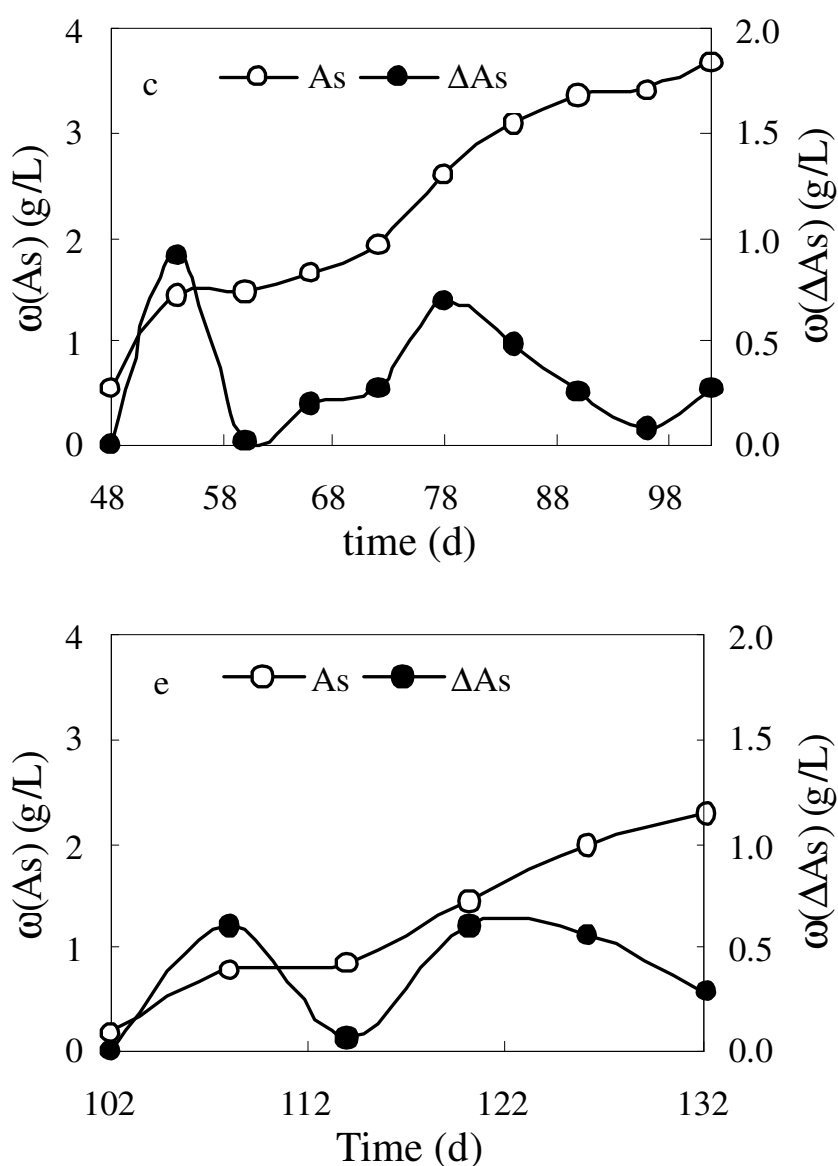

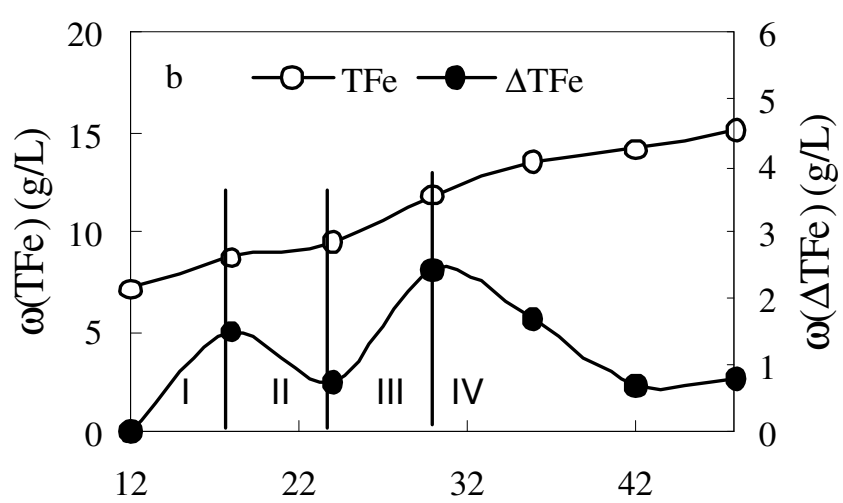

Time $(d)$
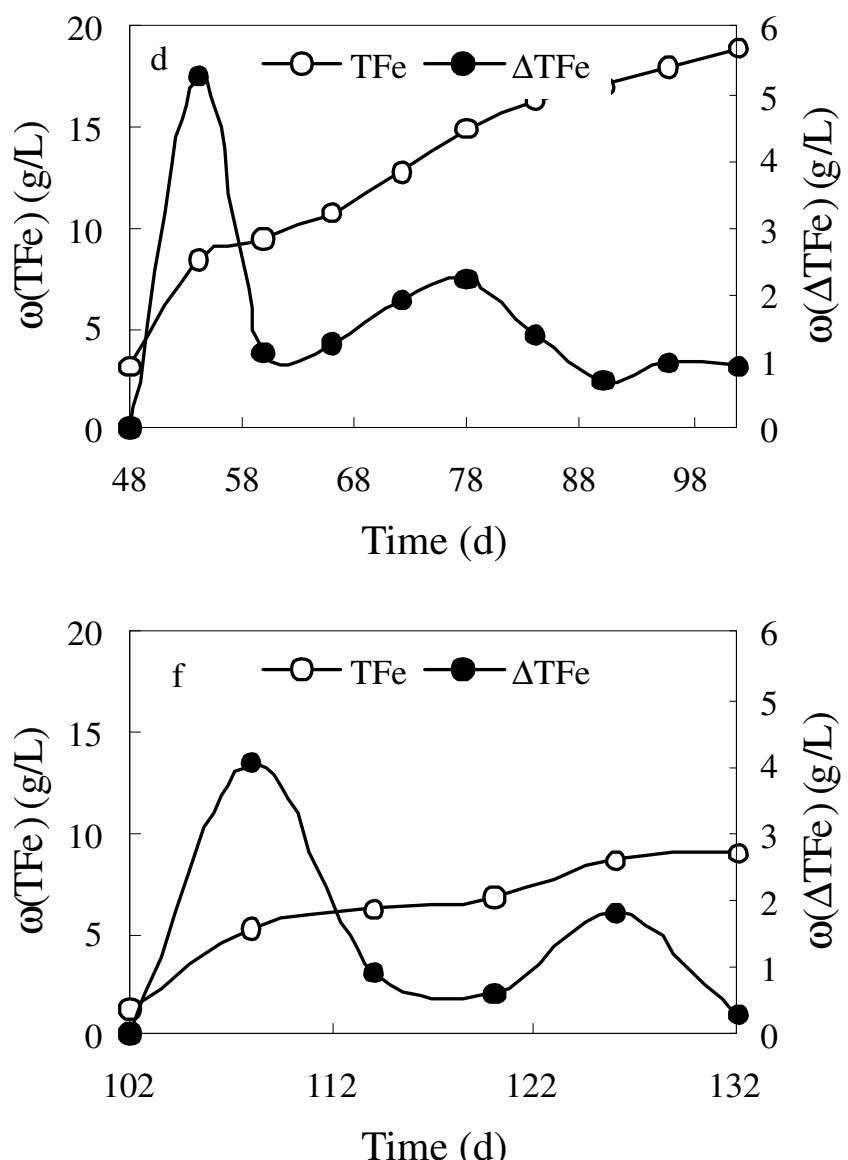

Fig. 6. Course time date of $\mathrm{TFe}, \Delta \mathrm{Fe}, \mathrm{As}$ and $\Delta \mathrm{As}$ in oxidation solution in column 3. a, c, e: As and $\Delta \mathrm{As}$ concentration in $12-48 \mathrm{~d}, 48-102 \mathrm{~d}$ and $102-132 \mathrm{~d}$, respectively; b, d, f: TFe and $\Delta$ TFe concentration in 12-48 d, 48-102 d and 102-132 d, respectively

$\mathrm{TFe}, \mathrm{As}, \mathrm{TFe}$ and $\triangle \mathrm{As}$ concentrations in column 3 were similar to those in column 2.

Preliminary economic assessment and further development: The process integration of the pretreatment of heap biooxidation with gold heap leaching for refractory gold concentrate is apparently less investment than the traditional processes of BIOX, BacTech, MINBAC and BIONC duo to the cheaper and fewer plants. Regarding the costs, Table- 3 lists the reagents consumption in our experiments. Table-3 demonstrated that relative to direct cyanidation process, $\mathrm{NaOH}$ consumption in column cyanidation greatly decreases while $\mathrm{NaCN}$ consumption increases after biooxidation pretreatment. The consumption of $\mathrm{H}_{2} \mathrm{SO}_{4}$ is up to $27.6-32.2 \mathrm{~kg} / \mathrm{t}$ related to the property of concentrate. They are an acceptable consumption from an economic point of view. Obviously, this process takes long time on pretreatment of the refractory concentrate and its economical feasibility needs further evaluation.

\begin{tabular}{ccccc}
\multicolumn{5}{c}{ TABLE-3 } \\
\multicolumn{5}{c}{ REAGENTS CONSUMPTION IN COLUMN } \\
LEACHING PROCESSES \\
\hline Column & $\mathrm{H}_{2} \mathrm{SO}_{4}(\mathrm{~kg} / \mathrm{t})$ & $\mathrm{NaOH}(\mathrm{kg} / \mathrm{t})$ & $\mathrm{NaCN}(\mathrm{kg} / \mathrm{t})$ & Cement $(\mathrm{kg} / \mathrm{t})$ \\
\hline $\mathrm{C}_{1}$ & - & 4.30 & 1.34 & 8.0 \\
$\mathrm{C}_{2}$ & 32.2 & 1.77 & 2.19 & 5.0 \\
$\mathrm{C}_{3}$ & 30.5 & 1.65 & 2.25 & 5.0 \\
$\mathrm{C}_{4}$ & 27.6 & 1.51 & 2.52 & 5.0 \\
\hline
\end{tabular}


In further studies, the application of the thermo-tolerant bacteria may be an effective ways to shorten the biooxidation time and a practice of aerating column may be performed to alleviate the low aeration in the bioleaching column.

\section{Conclusion}

The highest gold extraction rate is up to $88.86 \%$ for refractory concentrates using column bioleaching over the range of temperature of $15-28^{\circ} \mathrm{C}$ in oxidation times of 60 $306 \mathrm{~d}$, compared with the gold extraction rate of $39.97 \%$ in the conventional cyanidation process. To some extent, the heap bioleaching is a potential process for refractory arsenic gold concentrate.

The results show that the extraction rate of gold is positively proportional to that of arsenic by either column bioleaching or agitated bioleaching and can be expressed by a linear equation. In bioleaching solutions, the measured potential is affected by the multi-electron pair potential. The potential of $\mathrm{Fe}^{3+} / \mathrm{Fe}^{2+}$ was primary one. The TFe and $\Delta \mathrm{As}$ concentrations in solution exhibit periodicity fluctuation, which reflects the activity of the bacteria and probably is related to the bacterial adaptability to high ion concentrations

The process integration of the pretreatment of heap biooxidation with gold heap leaching for refractory gold concentrate is apparently less investment than the traditional processes and its reagents costs are acceptable.

\section{ACKNOWLEDGEMENTS}

The authors gratefully acknowledged the financial support by National Natural Science Foundation of China (41072184) and the Special Fund for Basic Scientific Research of Central Colleges, Chang'an University(CHD2011ZD019). Xiao-yan Zhang, Li-Qun Wang and Fang-ling Zhao partly conducted the experiment. The authors also thank Rorbert F. Diffendal for his English revision to the manuscript.

\section{REFERENCES}

1. J.A. Brierley and C.L. Brierley, Hydrometallurgy, 59, 233 (2001).

2. C.F. Bonney, E. Pehrsson and G. Sodermark, Miner. Eng., 15, 871 (2002).

3. C.J. Zheng, H. Zhang and M.K. Feng, Gold, 21, 31 (2000) (Chinese with English abstract).

4. M.I. Sampson, W. Van der Merwe, T.J. Harvey and M.D. Bath, Miner. Eng., 18, 427 (2005).

5. Z.G. Quan, J. East China Geol. Inst., 19, 224 (1996) (Chinese with English abstract).

6. S. Ubaldini, F. Veglio and L. Toro, Miner. Process., 52, 65 (1997).

7. M. Nemati, S.T.L. Harrison and G.S. Hansfor, Biochem. Eng. J., 1, 171 (1998).

8. A.B. Jensen and C. Webb, Process. Biochem., 30, 225 (1995).

9. R. Cruz, I. Lazaro, I. Gonzalez and M. Monroy, Miner. Eng., 18, 1024 (2005).

10. B. Escobar and D. Lazo, Hydrometallurgy, 71, 173 (2003).

11. D. Nestor, U. Valdivia and A.P. Chavaes, Int. J. Miner. Process., 62, 187 (2001).

12. A.W. Breed and G.S. Hansford, Miner. Eng., 12, 383 (1999).

13. M. Boon, Hydrometallurgy, 62, 67 (2001).

14. H. Tributsch, Hydrometallurgy, 59, 177 (2001).

15. C. Gomez, J.L. Limpo and A. Deluis, Can. Metal. Quart., 36, 15 (1997). 